\title{
Risky behavior regarding drug use and HIV infection: an Internet questionnaire coupled with short education texts for Portuguese speakers
}

\author{
Comportamento de risco para uso de drogas e infecção pelo HIV: \\ questionário na internet acoplado com textos educacionais \\ para língua portuguesa
}

\author{
Leila Strazza ${ }^{1}$, Raymundo S. Azevedo ${ }^{2}$ and Heráclito B. Carvalho ${ }^{3}$
}

\begin{abstract}
Surveys of risky behavior relating to HIV/AIDS are generally made for groups at risk of infection, for which HIV/AIDS prevalence is usually expected to be higher than in the general population. Therefore, an educational homepage in Portuguese was created on the Internet to inform/ask internauts regarding knowledge and behavior. The internauts were classified as adolescents (13 to 25 years) and adults (>25 years). The number of STDs was reported as $1.8 \pm 2.6$ infections (range: 1 to 20 infections); $43 \%$ used condoms during sexual intercourse. Alcohol consumption was reported by $63 \%$ and illicit drug use by $32 \%$ (marijuana $24 \%$ and inhalants $15 \%$ ). Among the adolescents, $31 \%$ did not classified alcohol as a drug. The adults more frequently reported homosexuality, anal intercourse and STDs, although the adolescents also presented high rates of risky behavior. These results show the need to reach out to internauts through better control strategies. Different types of strategies must be encouraged, in order to reach people that use this means of communication and entertainment.
\end{abstract}

Key-words: HIV/AIDS. Internet. Sexual risk. Vulnerability. Adolescents and adults.

\section{RESUMO}

Levantamentos de comportamento de risco para HIV/AIDS são geralmente feitos para grupos de risco onde a prevalência é normalmente esperada ser maior que na população geral. Assim, foi criada uma homepage educacional em português para informar/perguntar sobre conhecimento e comportamento aos internautas. Os internautas foram classificados em grupos: adolescentes (13 a 25a) e adultos (>25a). DST foi relatada como 1,8 \pm 2,6 infecções (intervalo de 1 a 20 infecções); 43\% usaram preservativo durante ralação sexual. Álcool foi referido por $63 \%$, droga ilícita por $32 \%$ (maconha $24 \%$ e inalantes 15\%). Trinta e um por cento dos jovens não classificaram álcool como droga. Adultos referiram maior freqüência em homossexualismo, sexo anal e DST, embora jovens apresentem altas taxas no comportamento de risco. Os resultados mostram necessidade de atingir internautas com melhores estratégias de controle. Diferentes tipos de estratégias devem ser encorajados, a fim de alcançar pessoas que usam este meio de comunicação e de entretenimento.

Palavras-chaves: HIV/AIDS. Internet. Risco sexual. Vulnerabilidade. Adolescentes e adultos.

Surveys of risky behavior relating to HIV infection are generally made for specific groups like injectable drug users, prostitutes and prisoners, for example, for whom the prevalence of this disease is expected to be higher than in the general population.

To this end, much effort has been put into developing tools for applying questionnaires and role playing techniques that give preference to these specific groups, both for mapping out their behavior and planning intervention strategies to reduce HIV infection, coupled with educational programs ${ }^{2}$.
Face-to-face interviews are usually applied in surveys of risky behavior among disadvantaged youths and other prisoners who are serving time in correctional facilities ${ }^{1413}$, because of their illiterate condition $^{2}$. Such interviews are also applied to injectable drug users ${ }^{18}$.

Computerized interfaces have been used in order to reduce the underreporting of risky behavior regarding HIV infection among injectable drug users ${ }^{3}$. They have been shown to be a valuable tool for assessing the dynamics of HIV transmission, but again in a limited group at risk.

\footnotetext{
1. Oscar Freire Institute, School of Medicine, The University of São Paulo, São Paulo, SP. 2. Department of Pathology, School of Medicine, The University of São Paulo, São Paulo, SP. 3. Department of Preventive Medicine, School of Medicine, The University of São Paulo, São Paulo, SP.

Address to Dr. Leila Strazza. Disciplina de Informática Médica/Instituto Oscar Freire/FMUSP. R. Teodoro Sampaio 115/10 andar, 05405-000 São Paulo, SP, Brasil.

Tel: 5511 3061-7682; Fax: 5511 3062-6018

e-mail: strazza@usp.br

Recebido em: 21/08/2006

Aceito em: 20/06/2007
} 
These approaches have been only partially successful in their objectives, because they left out most of the potential population at risk of HIV infection that is fully in touch with these specific groups, namely, adolescents and heterosexual adults (both male and female).

One option is to use the Internet, although it must be borne in mind that people doing this need to have a certain level of literacy and some skill to run the procedures when accessing web pages. The recent popularization of the Internet through the World Wide Web (www) interface in Brazil has made it possible to use this approach for surveys among www users, who will hereafter be named "internauts" in this article. The Internet is offering opportunities to 15 million Brazilians who are accessing it every day ${ }^{10}$.

This group provides good opportunities for studying a variety of subjects, and in this case specific characteristics of behavior and habits. There are many advantages in surveying this population, including a large range of ages and social classes, different genders and sexual orientations, anonymity favoring true answers, ease of processing the data collected, and last but not least the possibility of representing the population in general. Therefore, this kind of approach may differ from traditional data collection methods ${ }^{11}$.

In order to offer an educational source for HIV/AIDS we have created a homepage (http://www.saudetotal.com/strazza.htm) for sexual behavior and risky habits relating to HIV infection ${ }^{17}$ 1516. This study aimed to determine the profile of this group of Portuguese-speaking internauts.

\section{PATIENTS AND METHODS}

A quantitative method was applied through a self-administered questionnaire.

Target population. The target population consisted of Portuguese speakers and readers who are internauts. Portuguese is spoken on four continents: Europe, Africa, Asia and the
Americas. The largest population of Portuguese speakers lives in Brazil, comprising 180 million inhabitants 5 . The numbers of internauts are increasing rapidly in Brazil, and fastest in the southern portion of the country, thus constituting a population of more than 10 million internauts ${ }^{6}$.

In order to apply this survey to this population, we linked the questionnaire web pages to a Brazilian site dedicated to health topics called Saúde Total (Total Health: http://www.saudetotal. com), which counts more than a hundred thousand hits per month.

Questionnaire design. The questionnaire was designed to investigate predictions regarding internauts' vulnerabilities and sexual and drug use behavior, and the resources they used to obtain information on sexual health. The respondents reported the number of sexual partners they had had over the past 30 days, half year and lifetime. Their histories of sexually transmitted diseases (STDs) and drug use were also investigated.

It is important to know about the internaut's profile, and thus they were also asked questions about their age, sex, schooling level, country, HIV status (positive or negative), whether they were disabled or not, and so on. When internauts entered the web page, they were informed that their privacy would be maintained throughout their visit to the site.

The site was programmed to drive the internaut to the appropriate questionnaire, according to the respondent's age.

When the internauts started to answer the questionnaire, they could stop at any time and restart it later on, returning to the last part that was filled in. Despite the challenging way in which the questions were presented, the process of filling it out took some time because of the need to reflect on the responses (Figure 1).

The homepage was presented as a survey on sexual behavior, from which internauts would be able to recognize their own vulnerability to HIV transmission through an educational selfapplied questionnaire. The questionnaire measured internauts' behavior in three different age groups: 13 to 24, 25 to 59 and 60 years or over. Web site users aged 12 years or under were directed

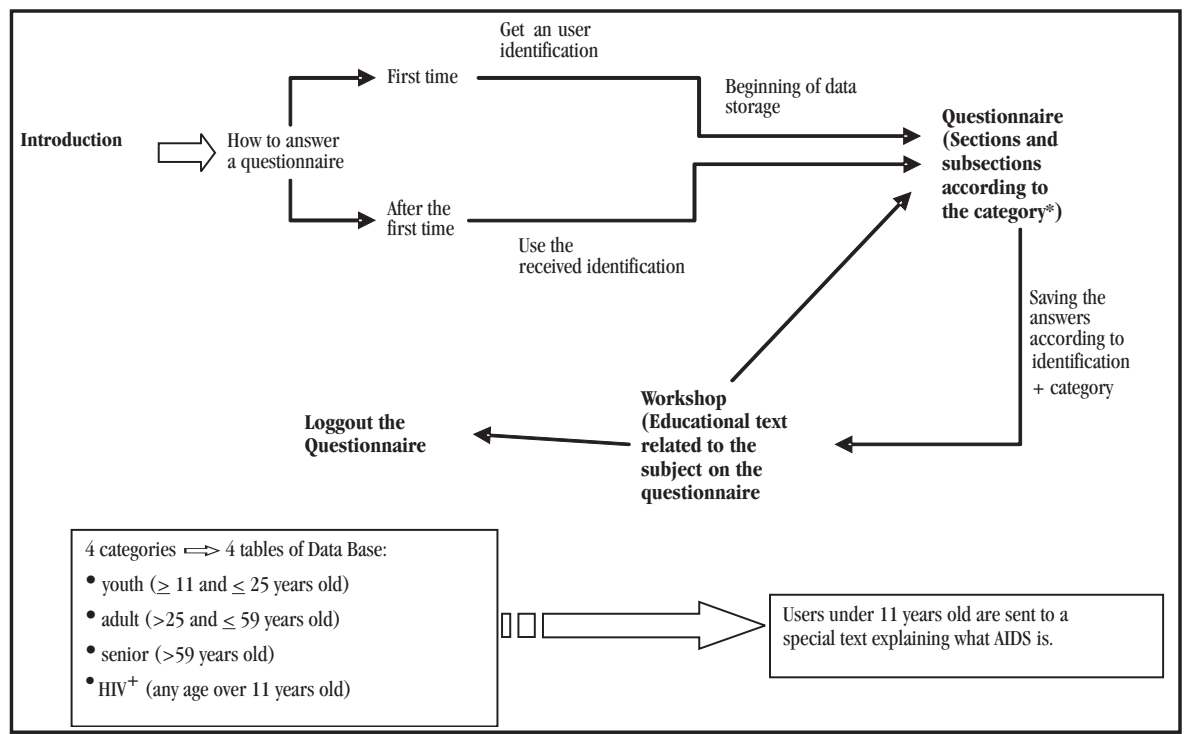

Figure 1 - Flowchart showing the sequence internauts go through when answering the questionnaire. 
to a special text explaining what AIDS is. In this paper, we have chosen to classify the respondents into two groups: adolescents and adults. The adolescents were defined as individuals from 13 to 24 years old and adults as individuals aged 25 years or over.

The city where the internaut lived was classified as follows: small, less than 50,000 inhabitants; medium-sized, from 50 to 100,000 inhabitants; and large, more then 100,000 inhabitants.

Questions about weight and height were used in this questionnaire, not only to help in building up the internauts' profile, but also to help to ensuring data accuracy. Males tend to be heavier and taller than females, in random population samples.

The respondents' length of formal education was classified as elementary level, less than 8 years; high school, from 8 to 11 years; undergraduate, from 11 to 14 years; graduate, from 14 to 16 years; postgraduate, more than 16 years.

Stages of the questionnaire. The questionnaire presented questions or sets of questions composed of sections or stages as follows: sex; life situation; disabilities, sexual behavior and habits; sexual partners; sexual activity over last 6 and 12 months; STDs; drugs and alcohol; and beliefs, habits and knowledge regarding HIV/AIDS. When they finished filling out each stage of the questionnaire, the computer displayed texts that contained situations similar to the questions they had just answered ${ }^{12}$.

Web site: These Brazilian web pages were produced using Microsoft FrontPage® 98 (file suffixes “.idc”, Internet database connector, and ".htx", modified hypertext). The responses to the questionnaire were stored in database files that were produced using Microsoft Visual Fox ® Pro 5.0 and utilized ODBC technology (open database connectivity).

Data collection. The data were collected in the city of São Paulo, Brazil, using the Internet 24 hours a day, from January 2003 to January 2004.

Statistical analyses. The questionnaire variables were tested by cross-tabulating and applying the $\chi^{2}$ test or Fisher's exact test, with calculation of odds ratios (OR) and $p$ values. Student's $t$ test was used to determine differences in continuous variables between groups, assuming unequal variance when Levine's test for equality of variance was significant at $\mathrm{p}<0.05^{7}$. The software used was Epi-Info version 6 and Stata 8.0.

\section{RESULTS}

From this survey, 770 completed questionnaires were obtained and all others that were partially answered were excluded. Among the respondents of the completed questionnaires, 350 (45\%) were adolescents and 420 (55\%) were adults. As expected, most of the responses came from Brazil (91\%), but there was also some internauts from Portugal (7\%; 56 individuals) and the United States, Angola, Mozambique, Japan and China (less than 1\%).

The mean age of the adolescents was $20.5 \pm 3.0$ years and the mean for the adults was $35.3 \pm 7.8$ years. The oldest respondent was 70 years old. There were more male respondents among the adults than among the adolescents ( $46 \%$ and $36 \%$ respectively, $\chi^{2}=4.5, p=0.03$ ).
The respondents' schooling levels are presented in Table 1. The mean length of formal education was higher among the adolescents than among the adults (13.0 versus 10.8 years, Student's t test $=7.6 ; \mathrm{p}<0.0001)$.

Table 1-Formal education among adolescents and adults obtained in an Internet survey, São Paulo, Brazil - 2003 ( $\chi_{\text {Pearson }}^{2}=81.5$; <0.0001).

\begin{tabular}{|c|c|c|c|c|c|c|}
\hline \multirow[b]{2}{*}{ Formal education* } & \multicolumn{2}{|c|}{ Adolescents } & \multicolumn{2}{|c|}{ Adults } & \multicolumn{2}{|c|}{ Total } \\
\hline & $\mathrm{n}^{0}$ & $\%$ & $\mathrm{n}^{0}$ & $\%$ & $\mathrm{n}^{0}$ & $\%$ \\
\hline $1^{\text {st }}$ degree & 19 & 4 & 7 & 2 & 26 & 3 \\
\hline $2^{\text {nd }}$ degree & 202 & 50 & 128 & 37 & 330 & 44 \\
\hline Under graduation & 71 & 18 & 43 & 12 & 114 & 15 \\
\hline Graduate & 66 & 16 & 33 & 9 & 99 & 13 \\
\hline Pos doc & 46 & 11 & 137 & 39 & 183 & 24 \\
\hline Total & 404 & 100 & 348 & 100 & 752 & 100 \\
\hline
\end{tabular}

*Years of formal education - $1^{\text {st }}$ degree $(0 \mid-8 \mathrm{y}) ; 2^{\text {nd }}$ degree $(8 \mid-11 \mathrm{y}) ;$ still in University (11 $\mid-14$ y); University $(14 \mid-16 y)$; pos graduation (grater the 16y)

There was equal distribution between the adolescent and adult groups with regard to disability and with regard to gender: $2 \%$ (9) and 3\% (12) respectively, with no statistical difference. HIV-positive status was reported by $3 \%$ (20), equally distributed between gender and age groups. A history of transfusion was reported by $1 \%$ (5) of the adolescents and $7 \%$ (26) of the adults, $\chi^{2}=18.9, \mathrm{p}<0.0001$, with no difference between the genders.

According to marital status they were distributed into two groups: living with a partner or not. Twenty-one percent (39) of the adolescents were living with someone, versus $79 \%$ (146) of the adults $\left(\chi^{2}=105, \mathrm{p}<0.0001\right)$. There was also a difference between genders: $39 \%$ (92) of the men were living with someone, versus $29 \%$ (93) of the women $\left(\chi^{2}=6.1, \mathrm{p}=0.01\right)$.

The mean weight reported was $77 \pm 15 \mathrm{~kg}$ for the men (range: 42 to $104 \mathrm{~kg}$ ) and $60 \pm 13 \mathrm{~kg}$ for the women (range: 35 to $104 \mathrm{~kg}$ ). There was a statistical difference between the men and women $(\mathrm{p}<0.0001)$, as expected. The mean height reported was $175 \pm$ $12 \mathrm{~cm}$ for the men (range: 140 to $199 \mathrm{~cm}$ ) and $162 \pm 11 \mathrm{~cm}$ for the women (range: 140 to $184 \mathrm{~cm}$ ). Again, a statistical difference was observed $(\mathrm{p}<0.0001)$.

Most of the internauts lived in large cities, representing $44 \%$ (250) of the total, but 29\% (167) lived in medium-sized cities, 19\% (109) in small cities and 8\% (43) outside of cities. There were no statistical differences in distribution between adolescents and adults.

Catholicism was the most frequent religion with 56\% (318), followed by Spiritualism 13\% (75), Evangelism 11\% (61) and others 7\% (39). Thirteen (76) percent did not declare any religion. There was no statistical difference between genders, but the adolescents were more frequently Catholic than were the adults: $61 \%$ (180) versus 51\% (138), respectively $\left(\chi^{2}=6.1\right.$, $\mathrm{p}=0.01$ ).

Adolescents mostly lived with their relatives $(74 \% ; 219)$ and adults mostly lived with a partner $(83 \% ; 144)$. Living alone was reported by 63 internauts, of whom $62 \%$ (39) were adults.

Concerning sexual relationships, 19\% (91) reported that they were not living with a partner at that moment, among whom 
there were more adolescents $(67 \% ; 61)$ than adults $(33 \% ; 30)$ $\left(\chi^{2}=11.5, \mathrm{p}=0.001\right)$. Thirty-three percent (117) reported sexual relations with casual partners and 70\% (270) reported that they had one steady partner. There were no differences between the age groups regarding the number of partners: on average 3.7 and 2.5 among adults and adolescents respectively $(t=1.6, p=0.05)$. Concerning sexual activity, 9\% (46) declared that they were virgins, among whom there were more adolescents then adults (93\% and $7 \%$ respectively: $\chi^{2}=32.3 ; \mathrm{p}<0.0001$ ). Some of the variables relating to differences in risky sexual behavior between these groups are summarized in Table 2.

Table 2 - Selected variables differences on sexual risk behaviors between adults (A) and adolescents (Y) obtained in an Internet survey, São Paulo, Brazil - 2003.

\begin{tabular}{lrrrrrrr}
\hline Variables & $\mathrm{n}^{\mathrm{0}}$ & $\mathrm{N}$ & \%A / \% & OR & CI 95\% & $\chi^{2}$ & $\mathrm{p}$ \\
\hline Homosexual & 55 & 476 & $16 / 7$ & 2.4 & $1.3-4.5$ & 8.6 & 0.003 \\
Anal intercourse & 236 & 478 & $60 / 40$ & 2.5 & $1.7-3.6$ & 23.4 & 0.0001 \\
Insertive & 132 & 478 & $60 / 40$ & 1.8 & $1.2-2.8$ & 7.9 & 0.005 \\
Receptive & 118 & 478 & $62 / 38$ & 2.0 & $1.4-3.2$ & 12.6 & 0.0004 \\
STD & 57 & 337 & $24 / 10$ & 2.8 & $1.5-5.1$ & 11.4 & 0.0008 \\
\hline
\end{tabular}

$\mathrm{A}$ - adults (older than 25 years old); $\mathrm{Y}$ - adolescents (from 13 to 25 years old); $\mathrm{n}^{\mathrm{0}}=$ cases $\mathrm{N}=$ respondents. STD: sexually transmitted disease. OR: odds ratio; CI: confidence interval

No difference between the age groups were found regarding the number of STDs and condom use: $1.8 \pm 2.6$ infections on average (range: 1 to 20) and $43 \%$ (174) used condoms. Concerning drug use, 63\% (216) reported using alcohol and 32\% (110) used illicit drugs. Thirty-one percent of the adolescents (57) believed that alcohol was not a drug, versus $41 \%(65)$ of the adults $\left(\chi^{2}=4.8 ; \mathrm{p}=0.03\right)$. The illicit drug most used was marijuana $24 \%$ (80), followed by inhalants $15 \%$ (52). There was no difference between the age groups.

In addition to these data, it is important to mention that a huge number of emails were sent to the site, asking many questions about AIDS and, more importantly, asking for personal advice.

\section{DISCUSSION}

There are some limitations to online data collection that should be noted. One of them, according to Turner ${ }^{18}$, concerns the level of privacy that this interview method provides for respondents, which may affect the behavioral measurements. Moreover, it requires that the individual is sufficiently literate to complete the questionnaire. Even literate respondents may have doubts about the instructions while going through web pages.

McFarlane ${ }^{9}$ agreed with Turner ${ }^{18}$ and stated that online surveys had obvious limitations because respondents would be able to lie about any subject. For example, online surveys may encourage false reporting of age, considering that anyone under the age of 12 years was excluded from participation. Declarations regarding marital status or even sexual activity and drug use could similarly be affected.

But we can also agree with Scott ${ }^{11}$ and Fernandez $z^{4}$, who highlighted that internauts feel safe and may have no fear when answering questions because they do not see any negative social consequences from doing so.
This kind of online research about people's behavior gives rise to a plentiful supply of research resources. Moreover, there is no need to train interviewers for applying the questionnaires, savings on paper and printing, and no need for a special time and place for answering the questions. Also, with a written questionnaire, respondents can skip items if they do not like them or forget to answer them. However, such problems can be eliminated with the web-based method ${ }^{11}$, since internauts will be unable to make progress through the web pages unless they answers all the mandatory questions in a given section.

It should also be mentioned that the potential error in results that an interviewer's interpretation could introduce when applying a questionnaire is reduced when a computer-based questionnaire is used and the respondent's interaction is standardized, thereby reducing interviewer bias ${ }^{11}$.

It should be remembered that this is the $21^{\text {st }}$ century, in which new technologies are being applied every day. Thus, it is very important to pay attention to the new habits that people acquire, including the Internet and all the kinds of information that it conveys ${ }^{10}$. Despite the limited accuracy of these kinds of data, this approach encourages internauts. According to Mann et $\mathrm{al}^{8}$, this provides a social answer as well as the idea of changing the behavioral patterns.

This online research provided internauts with an educational health program. Thus, on reaching the end of each stage, the computer program presented them with some texts. This approach is based on Skinner's learning techniques ${ }^{12}$, which use reinforcement as an education program. These analyses are not presented in this paper.

The means for weight and height reported for the men were greater than for the women. This was, as expected, a statistically significant difference $(\mathrm{p}<0.0001)$ and it adds credence to the hypothesis that the data are accurate.

Both age groups were formed by individuals with a good level of formal education, although the adolescents presented a larger number of formal years of study. This high level concords with the idea that the questionnaires could be well interpreted, thereby minimizing self-application bias.

One special result from this study was that there was little evidence that adolescents were able to identify alcohol as a drug. For drug prevention programs to reach their aims, they need to continually stress that alcohol is also a drug. In both age groups, the prevalence of drug use was high. Harm reduction movements need to have at least one foot firmly planted in public health ${ }^{1}$.

Notwithstanding the research goal, it is important to again highlight the e-mail messages received, which not only expressed the internauts' doubts regarding HIV/AIDS, but also asked for solutions for personal questions. It should be noted that this online research forms part of the website: http://www.saudetotal.com.

\section{ACKNOWLEDGEMENTS}

The authors are greatly indebted to the staff of the Disciplines of Telemedicine (LIM 34) and Medical Information Technology (LIM 01) for their continual efforts to keep this project running. 


\section{REFERENCES}

1. Burris S. Harm reduction's first principle: "the opposite of hatred" International Journal of Drug Policy 15:243-244, 2004.

2. Catania JA, Kegeles SM, Coates TK. Towards an understanding of risk behavior: an AIDS risk reduction model (arrm). Health Education 17: 53-72, 1990.

3. Des Jarlais DC, Paone D, Milliken J, Turne CF. Miller H, Gribble J, Shi Q, Hagan H, Friedman SR. Audio-computer interviewing to measure risk behavior for HIV among injecting drug users: a quasi-randomised trial. Lancet 342:1657-1661, 1999.

4. Fernandez MI, Perrino T, Collazo JB, Varga LM, Marsh D, Hernandez N, Rehbein A, Bowen GS. Surfing New Territory: Club-Drug Use and Risky Sex Among Hispanic Men Who Have Sex Recruited on the Internet. Journal Urban Health, 2005.

5. Instituto Brasileiro de Geografia e Estatística. Brazilian Institute for Geography and Statistics. http://www.ibge.gov.br, 2006.

6. Instituto Brasileiro de Opinião Pública e Estatística. Brazilian Institute for Public Opinion and Statistics. http://www.ibope.com.br/digital/pd_wef00.htm, 2000.

7. Kleinbaum DG, Kupper LL, Muller KE, Nizam A. Applied regression analysis and other multivariate methods ( $3^{\text {rd }}$ edition). Pacific Grove, CA, Brooks/Cole, 1998.

8. Mann J, Tarantola DJM, Netter TW. A AIDS no Mundo, Relume-Dumará, Rio de Janeiro, 1993.

9. McFarlane M, Bull SS, Rietmeijer CA. Young Adults on the Internet: Risk Behaviors for Sexually Transmitted Diseases and HIV. Journal Adolescent Health 31: 11-16, 2002.

10. Science Panel On Interactive Communication And Health Wired for Health and Well-Being. The emergence of interactive health communications. Government Printing Office, Washington, 1999.
11. Scott DR, Ralph JDC, Heather C, Kenneth CH, Leland JY. Risk Among Men Who Have Sex With Men in The United States: A Comparison of An Internet Sample And A Conventional Outreach Sample, AIDS Education Prevention 14: 41-50, 2002.

12. Skinner BF. Tecnologia do Ensino. EPU e EDUSP, $2^{\text {a }}$ edição, São Paulo, 1972.

13. Strazza L: Diferenças de gênero e risco para a infecção pelo HIV em adolescents internos na Fundação Estadual Para o Bem Estar do Menor de São Paulo - FEBEM (tese de mestrado). Área de Fisiopatologia Experimental da Faculdade de Medicina da Universidade de São Paulo. http://www.teses.usp.br/teses/ disponiveis/5/5160/tde-26042006-110406/, 1999.

14. Strazza L, Azevedo RS, Carvalho HB, Massad E: The vulnerability of Brazilian female prisoners to HIV infection. Brazilian Journal of Medical and Biological Research 37: 771-776, 2004.

15. Strazza L, Azevedo RS, Chao LW, Silveira PSP, Oliveira MR, Böhm GM, Massad E. An Internet Risk Behavior for AIDS Survey. In: Anais do I Fórum e II Conferência de Cooperação Técnica Horizontal da América Latina e do Caribe em HIV/AIDS e STD, volume II, p. 950, Rio de Janeiro, 2000.

16. Strazza L, Azevedo RS, Chao LW, Silveira PSP, Oliveira MR, Bohm GM, Massad E. Risk behavior for AIDS: an Internet questionnaire coupled with short texts on safe sex and drug harm reduction for Portuguese speakers, CIP2000. In: Abstract of the Computers in Psychology Conference, University of York, York, p. 38,2000 .

17. Strazza L, Azevedo RS, Massad E, Carvalho HB. Risk behavior for drug use and AIDS infection: an Internet questionnaire coupled with short education texts for Portuguese Speaker. In: Resumo of the $17^{\text {th }}$ International Conference on the Reduction of Drug Related Harm. Vancouver, p.128-129, 2006.

18. Turner CF, Lessler JT, Gfroerer JC. Survey measurements of drug use: methodological studies, Washington, United State Government Printing Office, 1992. 